Journal of Community Based Environmental Engineering and Management, 2020, Vol. 4, No. 1: 1-8

\title{
PARTICIPATION OF LOCAL RESTAURANTS IN SOLID WASTE MANAGEMENT IN SOUTH COAST OF GUNUNGKIDUL REGENCY, INDONESIA
}

\author{
Jussac Maulana Masjhoer ${ }^{1}$, Aditano Yani Retawimbi ${ }^{2}$, Yenita Sandra Sari ${ }^{3}$ \\ 1) 2) Study Program of Tourism, Sekolah Tinggi Pariwisata Ambarrukmo Yogyakarta \\ ${ }^{3)}$ Study Program of Environmental Engineering, Universitas Kebangsaan
}

\begin{abstract}
Restaurants also contribute to the generation of solid waste in tourism destinations. Participation needs to be identified because restaurants participate in utilizing and getting benefits from the tourism development. This research aims to analyze the participation of restaurants in solid waste management started from the planning stage, implementation stage, benefit stage, and evaluation stage. The research is located on the beach Ngrenehan, Ngobaran Beach, Baron Beach, Sepanjang Beach, Kukup Beach and Drini Beach. The consideration that underlies location selection is the existence of restaurants and tourists. Quantitative data were collected using a questionnaire distributed to 48 restaurant owners. The data that has been collected is then processed using simple statistics to see the frequency and average. Simplified data were then analyzed using a qualitative descriptive approach and strengthened by the results of field observations and interviews. In general it can be concluded that restaurant owners actively participate in solid waste management. Participation in the planning stage was $73 \%$, the implementation stage was $66 \%$, the benefit taking stage was $100 \%$, and the evaluation stage was $81 \%$. Restaurant owners since the early stages of participation have shown positive activity. At the implementation stage, participation is influenced by the lack of knowledge and understanding related to the solid waste they have. Perception in taking benefits is influenced by how cleanliness of restaurants is felt to be beneficial both directly and indirectly. Participation in the evaluation was shown by the majority of respondents feeling that solid waste management was in accordance with planning and expectations.
\end{abstract}

Kata kunci: tourism impact, marine tourism, beach tourism, community participation, restaurant waste

\section{Introduction}

The development of the tourism sector in Gunungkidul Regency continues to grow as new beaches are opened along the South coast. Tourism is believed to bring benefits in the form of the creation of labor that comes from tourism facilities and travel companies that are labor

\footnotetext{
${ }^{1 *}$ Corresponding author

E-mail: jussacmaulana@stipram.ac.id

Received: 14 November 2019

Revised : 11 January 2020

Accepted: 14 February 2020
}

intensive so that it requires a lot of labor (Soekadijo, 1996). According to Lakshmi \& Shaji (2016), tourism like an industry also uses resources, creates waste, and creates environmental, social and cultural costs and benefits. There has been a drastic change in land use due to the construction of facilities intended for tourists.

This is marked by the growing number of accommodations, restaurants / restaurants and the number of tourists coming to Gunungkidul Regency. Based on data from Gunungkidul (2018), the number of tourists visiting tourist 
attractions in Gunungkidul District increased by $8.13 \%$, from 2.9 million tourists in 2016 to 3.2 million in 2017. In terms of tourism facilities, Gunungkidul on in 2017 there were 170 hotels or an increase of $39 \%$ from the previous year. Restaurants also experienced a very significant increase, from 168 in 2016 to 522 in 2017, an increase of more than $200 \%$.

Restaurants provide an economic contribution to a local community (Steva, 2017). The direct impact is in the form of employment and taxes on local government revenue. In addition to the positive benefits, the restaurant turns out to be one of the largest solid waste contributors in a tourism destination (Tatàno, Caramiello, Paolini, \& Tripolone, 2017). According to (Vaughn, 2009), restaurants produce waste such as food scraps, paper and cardboard, glass, metal, plastic, wood, and several types similar to household waste. The preparation process for cooking raw materials accounts for the largest solid waste, followed by leftover food from guests, depending on the type of restaurant and business model (Baldwin, Wilberforce, \& Kapur, 2011).

According to (Bashir \& Goswami, 2016), tourism produces the biggest solid waste during peak season. Weak institutional capacity, the availability of vacant land, the location of improper garbage collection infrastructure, and inadequate collection capacity are the source of the problem. Solid waste management is an activity carried out in handling waste from the time it is generated until the final disposal which includes technical and non-technical aspects (Damanhuri \& Padmi, 2010; Kartikawan, 2007).

Participation means the participation of a person or a group of people in the development process both in the form of statements and in the form of activities by providing input of thought, energy, time, expertise, capital and or material, and participate in utilizing and enjoying the results of development (Mardikanto \& Soebiato, 2015;
Sumaryadi, 2005) . Decision making processes related to the public interest require active involvement so that it becomes the core of community participation (Mikkelsen, 2011).

Community participation in a development can be seen from the initial stages, namely planning, preparation, or decision making. Next is the implementation stage, in waste management, the implementation includes the process of collection, transportation, and disposal. The next stage is the benefit-taking stage and finally the evaluation stage (Dwiyanto, 2011; Kaho, 2010; Solehati, Chaniago, \& Hutagaol, 2005; Wahyono, 2001).

Factors that encourage people to be willing and participate in waste management are knowledge of the environment, free time, and feeling lazy (Bhawal Mukherji, Sekiyama, Mino, \& Chaturvedi, 2016; Dhokhikah, Trihadiningrum, \& Sunaryo, 2015). In addition, participation is also influenced by socio-economic factors, discomfort, and sorting facilities (Han et al., 2019; Zeng, Niu, Li, Zhou, \& Zhao, 2016).

Based on the description above, this study aims to analyze the participation of restaurants in the management of solid waste in the South Coast tourist area of Gunungkidul Regency.

\section{Research Methodology}

This research uses mixed method approach. The approach was deemed appropriate because the obtained data can be more comprehensive, valid, reliable, and objective.

\section{Research Location}

This research is located along the southern coast of Gunungkidul Regency. Specifically, the selection of research locations is tourist beaches that have restaurants and are visited by tourists. Based on this, the tourist beaches used as sample locations are Ngrenehan Beach, Ngobaran Beach, Baron Beach, Sepanjang Beach, Kukup Beach and Drini Beach. 


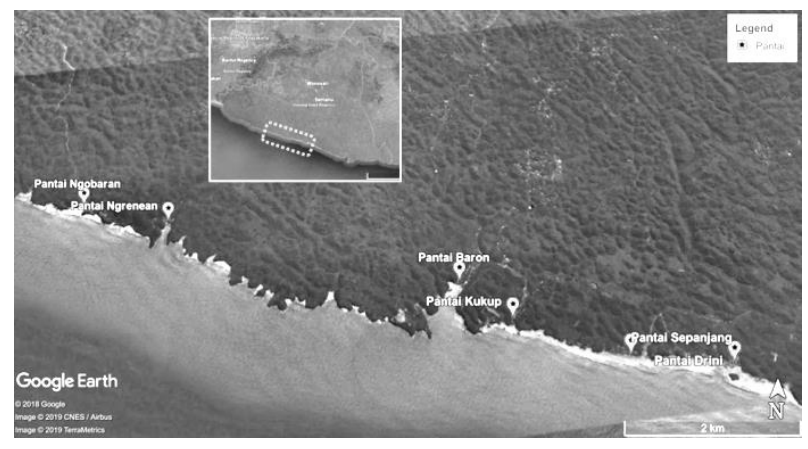

Figure 1. Map of research location.

\section{Tools and Materials}

The data required in this study is the assessment of respondents related to the variable in participation which is described in several stages, namely the Planning Phase, Implementation Phase, Benefit Stage, and Evaluation Phase.

The quantitative data is then processed using simple statistics to see the frequency and the average. The analysis was performed using a qualitative descriptive approach. Questionnaire data was collaborated with results of field observations and interviews.

The population in this study is the restaurant located in the study location. Determination of the number of samples is calculated proportionally using the Eq. 1 .

$s=\frac{n}{N} \times S$

Where:

$\mathrm{s}=$ Number of samples for each unit, proportionally

$\mathrm{S}=$ Number of acquired samples

$\mathrm{N}=$ Population number

$\mathrm{n}=$ Number of population unit

Based on Gunungkidul data (2018), there are 362 restaurants in the study location. According to the calculation results, there were 30 results. Consideration so that the entire coast obtained respondent data, then the sample is exaggerated up to 48 pieces.

\section{Result and Discussion}

The participation of restaurants in solid waste management can be seen from several stages, namely the preparation phase, the implementation phase, the benefit taking stage, and the evaluation stage. The core of restaurant participation is active involvement in the process of solid waste management in the public interest.

\section{Participation in Planning Stage}

In the planning stage $90 \%$ of restaurant owners follow the process of meetings related to waste management. $44 \%$ said they were not active in giving opinions or proposals at the meeting.

Table 1. Participation in Planning Stage

\begin{tabular}{lcc}
\hline \multicolumn{1}{c}{ Variable } & Yes & No \\
\hline $\begin{array}{l}\text { The activity of participating } \\
\text { in meetings related to waste } \\
\text { management }\end{array}$ & $90 \%$ & $10 \%$ \\
$\begin{array}{l}\text { Active in giving opinions / } \\
\text { suggestions }\end{array}$ & $56 \%$ & $44 \%$ \\
Average & $\mathbf{7 3 \%}$ & $\mathbf{2 7 \%}$ \\
\hline
\end{tabular}

In the planning stage, the average participation of restaurant owners is considered good, that is $73 \%$. Almost all restaurant owners are always present at meetings related to solid waste management and more than half of the respondents are willing to give an opinion. Decision making processes related to the public interest require active involvement so that it becomes the core of community participation (Mikkelsen, 2011). This shows that it can be said that restaurant owners on the south coast tourist beaches of Gunungkidul Regency since the beginning of the solid waste management planning process have shown active participation.

Restaurants on tourist beaches are villagers or hamlets around the beach. So we can be sure that each restaurant is a neighbor and knows each other. Absence from a meeting will be socially sanctioned. Social and cultural character 
has a great influence on participation (Puspitawati \& Rahdriawan, 2012).

\section{Participation in Implementation Stage}

As many as $79 \%$ of respondents do not know the difference in types of organic and inorganic waste and only $26 \%$ of respondents know that inorganic waste is dangerous and difficult to decompose naturally. Respondents of $88 \%$ did not try to reduce solid waste generation. Although not trying to reduce waste, as many as $42 \%$ claimed to reuse some of the garbage such as bottles and cardboard.

Waste sorting carried out by restaurant owners does not do the sorting process at the beginning of $98 \%$, so that inorganic and organic waste is mixed into one.

All restaurant owners have cleaning tools at their restaurant, regularly clean the stalls, collect garbage into the waste basket, routinely carry out community service activities, pay waste fees, and know and comply with regulations related to the garbage on the beach they occupy.

Table 2. Participation in Implementation Stage

\begin{tabular}{lcc}
\hline \multicolumn{1}{c}{ Variable } & Yes & No \\
\hline $\begin{array}{l}\text { Knowing the type of waste; } \\
\text { organic and non-organic }\end{array}$ & $21 \%$ & $79 \%$ \\
$\begin{array}{l}\text { Knowing that non-organic } \\
\text { waste is dangerous for the } \\
\text { environment and difficult to } \\
\text { be decayed }\end{array}$ & $21 \%$ & $79 \%$ \\
$\begin{array}{l}\text { Effort to reduce waste } \\
\text { generation }\end{array}$ & $12 \%$ & $88 \%$ \\
$\begin{array}{l}\text { Reuse plastic bag, cardboard, } \\
\text { bottle, paper, etc. }\end{array}$ & $42 \%$ & $58 \%$ \\
$\begin{array}{l}\text { Separate organic and non- } \\
\text { organic waste }\end{array}$ & $2 \%$ & $98 \%$ \\
$\begin{array}{l}\text { Preparing cleaning tools in } \\
\text { the restaurant }\end{array}$ & $100 \%$ & 0 \\
$\begin{array}{l}\text { Regularly handling the solid } \\
\text { waste generated in the } \\
\text { restaurant }\end{array}$ & $100 \%$ & 0 \\
$\begin{array}{l}\text { Collecting waste in the waste } \\
\text { container }\end{array}$ & $100 \%$ & 0 \\
Regularly conduct major & $100 \%$ & 0
\end{tabular}

cleaning

Pay the monthly retribution to the waste handling division Knowing the availability of regulation cencerning solid waste

Comply the waste management regulation

Average

\begin{tabular}{cc}
$100 \%$ & 0 \\
$100 \%$ & 0 \\
$100 \%$ & 0 \\
$\mathbf{6 6 \%}$ & $\mathbf{3 4 \%}$ \\
\hline
\end{tabular}

At the implementation stage, the average participation of restaurant owners in solid waste management is $66 \%$. The deduction factor in this implementation phase is basic knowledge about waste. Many restaurant owners do not yet understand the term organic and inorganic waste, and only understand it through the questionnaire content related to the type of waste. Their understanding, garbage in the form of cardboard and glass or plastic bottles can be sold to rubbers, without knowing the type and about the danger of inorganic waste to the environment and its difficult to decompose nature.

The initial stage of the waste management series begins with collection, which in this process also has the potential to reduce and separate solid waste. Restaurant owners are reluctant to reduce solid waste and separate by type. The lack of knowledge about solid waste and the environment can be a contributing factor. According to Zeng et al. (2016), obstacles in community participation to sort waste are awareness / knowledge about sorting, inconvenience, and lack of sorting facilities. In addition, feeling lazy also becomes one of the factors driving the community to be willing and participate in waste management in addition to basic knowledge and free time (Bhawal Mukherji et al., 2016; Dhokhikah et al., 2015). 


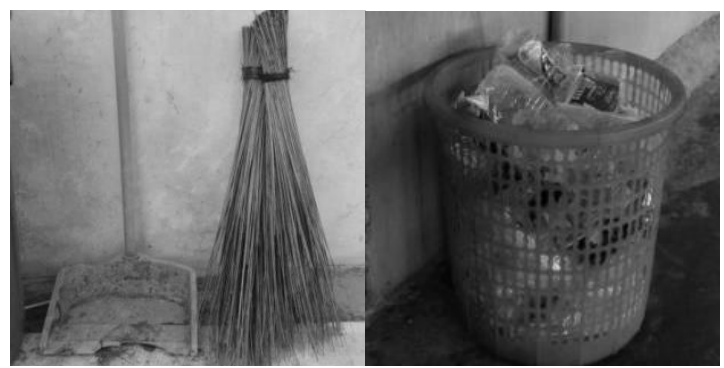

Figure 2. The cleaning tools in the restaurant.

Waste collection is also carried out by restaurant owners by cleaning their business premises routinely by using cleaning tools they have. The rubbish that is collected is then put into trash bins located around the beach. All beaches surveyed have a routine schedule of community service every Friday, including restaurants. One form of community participation in efforts to improve the environment is by providing labor contributions in the form of community service and participating in waste management and holding community meetings (Sulistiyorini, Darwis, \& Gutama, 2015).

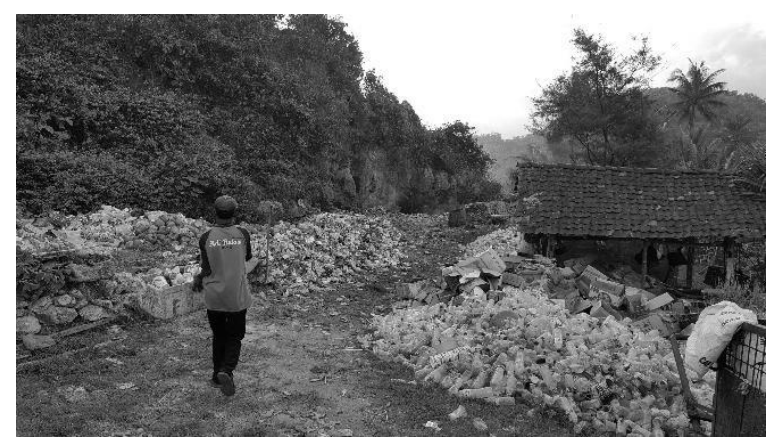

Figure 3. Separation of bottles and coconut shells.

The restaurant owner all said they knew and obeyed the rules that had been mutually agreed upon, including related to the waste charge. Han et al. (2019) states, willingness to pay and participate in waste management are influenced by socio-economic factors and environmental knowledge. Different opinions were conveyed by Paspitawati \& Rahdriawan (2012), who stated that the social and cultural character had a greater influence compared to the socio- economic character. It is reasonable to see restaurant owners who are on the tourist beaches along the southern coast of Gunungkidul Regency are residents in the nearest hamlet or village, so that it still has a strong Javanese culture.

\section{Participation in Taking the Benefits}

The results of the recapitulation of the questionnaire at the participation stage in taking benefits, all respondents (100\%) agreed that with the condition of a clean restaurant, then they are comfortable to work and assess the guests who come are also more comfortable.

Table 3. Participation in Taking Benefits

\begin{tabular}{lcc}
\hline \multicolumn{1}{c}{ Variable } & Yes & No \\
\hline $\begin{array}{l}\text { The convenience of } \\
\text { working in a clean } \\
\text { restaurant }\end{array}$ & $100 \%$ & 0 \\
$\begin{array}{l}\text { Comfort of guests in a } \\
\text { clean restaurant } \\
\text { Average }\end{array}$ & $100 \%$ & 0 \\
\hline
\end{tabular}

Respondents agreed that the benefits obtained from good solid waste management are comfort both from those who work and guests who come. The condition of a clean restaurant benefits both directly and indirectly. Here we see how understanding the benefits of cleanliness ultimately affect participation in solid waste management. This condition reinforces statements from Yuliastuti, Nyoman, Ayu, Yasa, Mahaendra, \& Jember, Made (2013) who argue that understanding, willingness, and community income simultaneously have a positive and significant effect on community participation in waste management.

\section{Participation in Evaluation Stage}

Participation in the evaluation phase assessed that $81 \%$ of respondents thought that the waste management that had been carried out by the community groups was in accordance with what 
was planned. $19 \%$ of respondents think otherwise.

Table 4. Participation in the valuation rate

\begin{tabular}{lcc}
\hline \multicolumn{1}{c}{ Variabel } & Yes & No \\
\hline $\begin{array}{l}\text { Waste management } \\
\text { according to planning and } \\
\text { expectations } \\
\text { Average }\end{array}$ & $81 \%$ & $19 \%$ \\
\hline
\end{tabular}

Respondents are of the opinion that the solid waste management carried out so far has been in accordance with planning and expectations. But there are still opinions that say otherwise. This is based more on the lack of basic knowledge related to waste that is not yet understood, so some respondents consider that solid waste management is not perfect. Public knowledge and perception related to solid waste becomes important if you want to manage solid waste properly and correctly (Haswindy \& Yuliana, 2018).

Good knowledge must also be accompanied by the support of qualified facilities in managing solid waste. The facility in question can be in the form of facilities to educate the public and waste facilities. Posmaningsih (2016) states, that the factors that influence community participation in waste management are facilities, economic benefits, local institutions, knowledge and attitudes. The facility factor is considered to be the factor that provides the most dominant contribution to community participation in waste management.

\section{Conclusion}

Based on the description and data presented above, it can generally be concluded that restaurant owners actively participate in solid waste management.

Restaurants since the early stages of participation have been active. At the implementation stage, participation is influenced by the lack of knowledge and understanding related to the solid waste they have. Perception in taking benefits is influenced by how cleanliness of restaurants is felt to be beneficial both directly and indirectly. Participation in the evaluation was shown by the majority of respondents feeling that solid waste management was in accordance with planning and expectations.

Knowledge related to the environment and solid waste management that is good and right needs to be conveyed to restaurant owners and the surrounding community so that the participation of restaurant owners is better. In the solid waste management procedure, the participation of restaurant owners can only be identified up to the garbage collection stage, whereas for transportation and the next stage has become the duty and authority of the janitor.

This research recommends an increase in education about solid waste management and the environment for restaurant owners and the surrounding community. Local governments need to facilitate solid waste infrastructure, especially on newly developed tourist beaches. Further research can be carried out by raising the topic of sustainable solid waste management strategies considering that the coastal area in Gunung Kidul Regency is on the Gunung Sewu Geopark site. The strategy includes technical aspects, stakeholder participation, regulations, funding, and institutional organizations.

\section{References}

Baldwin, C., Wilberforce, N., \& Kapur, A. (2011). Restaurant and food service life cycle assessment and development of a sustainability standard. The International Journal of Life Cycle Assessment, 16(1), 40-49. https://doi.org/10.1007/s11367010-0234-x

Bashir, S., \& Goswami, S. (2016). Tourism Induced Challenges in Municipal Solid Waste Management in Hill Towns: Case of Pahalgam. Procedia Environmental Sciences, $\quad 35, \quad 77-89$. https://doi.org/10.1016/j.proenv.2016.07.0 
48

Bhawal Mukherji, S., Sekiyama, M., Mino, T., \& Chaturvedi, B. (2016). Resident Knowledge and Willingness to Engage in Waste Management in Delhi, India. Sustainability, $\quad 8(10), \quad 1065$. https://doi.org/10.3390/su8101065

Damanhuri, E., \& Padmi, T. (2010). Pengelolaan sampah. Diktat kuliah TL, 3104, 5-10.

Dhokhikah, Y., Trihadiningrum, Y., \& Sunaryo, S. (2015). Community participation in household solid waste reduction in Surabaya, Indonesia. Resources, Conservation and Recycling, 102, 153162.

https://doi.org/10.1016/j.resconrec.2015.06 .013

Dwiyanto, B. M. (2011). MODEL PENINGKATAN PARTISIPASI MASYARAKAT DAN PENGUATAN SINERGI DALAM PENGELOLAAN SAMPAH PERKOTAAN *. Jurnal Ekonomi Pembangunan: Kajian Masalah Ekonomi Dan Pembangunan, 12(2), 239. https://doi.org/10.23917/jep.v12i2.196

Gunungkidul, B. P. S. K. (2018). STATISTIK DAERAH KABUPATEN GUNUNGKIDUL 2018. Badan Pusat Statistik Kabupaten Gunungkidul.

Han, Z., Zeng, D., Li, Q., Cheng, C., Shi, G., \& Mou, Z. (2019). Public willingness to pay and participate in domestic waste management in rural areas of China. Resources, Conservation and Recycling, 140(September 2018), 166-174. https://doi.org/10.1016/j.resconrec.2018.09 .018

Haswindy, S., \& Yuliana, F. (2018). Partisipasi Masyarakat Dalam Pengelolaan Sampah Pemukiman Pada Kecamatan Tungkil Ilir Kabupaten Tanjung Jabung Barat. Jurnal Ilmu Lingkungan, 15(2), 96. https://doi.org/10.14710/jil.15.2.96-111

Kaho, J. R. (2010). Prospek Otonomi Daerah di Negara Republik Indonesia.

Kartikawan, Y. (2007). Pengelolaan Persampahan. Jurnal Lingkungan Hidup. Yogyakarta.

Lakshmi, S. R., \& Shaji, T. L. (2016). Transformation of Coastal Settlements Due to Tourism. Procedia Technology, 24, 1668-1680. https://doi.org/10.1016/j.protcy.2016.05.18 8

Mardikanto, T., \& Soebiato, P. (2015). Pemberdayaan Masyarakat dalam Kebijakan Publik. Alfabeta.

Mikkelsen, B. (2011). Metode penelitian partisipatoris dan upaya pemberdayaan: panduan bagi praktis lapangan. Yayasan Pustaka Obor Indonesia.

Posmaningsih, D. A. A. (2016). Faktor-Faktor Yang Mempengaruhi Partisipasi Masyarakat Dalam Pengelolaan Sampah Padat Di Denpasar Timur. Jurnal Skala Husada, 13(1), 59-71.

Puspitawati, Y., \& Rahdriawan, M. (2012). Kajian Pengelolaan Sampah Berbasis Masyarakat dengan Konsep 3R (Reduce, Reuse, Recycle) di Kelurahan Larangan Kota Cirebon. JURNAL PEMBANGUNAN WILAYAH \& KOTA, 8(4), 349. https://doi.org/10.14710/pwk.v8i4.6490

Soekadijo, R. G. (1996). Anatomi pariwisata: memahami pariwisata sebagai "systemic linkage." Gramedia Pustaka Utama.

Solehati, M., Chaniago, I. A., \& Hutagaol, M. P. (2005). Studi tentang pengelolaan sampah padat rumah tangga di kota Meulaboh, kabupaten Aceh Barat provinsi Nanggroe Aceh Darussalam. IPB (Bogor Agricultural University).

Steva, L. (2017). How Restaurants Benefit The Local Economy. Retrieved November 13, 2019, from https://www.keloland.com/news/howrestaurants-benefit-the-local-economy/

Sulistiyorini, N. R., Darwis, R. S., \& Gutama, A. S. (2015). Partisipasi Masyarakat Dalam Pengelolaan Sampah Di. Share Social Work, 5(1), 71-80.

Sumaryadi, I. N. (2005). Perencanaan pembangunan daerah otonom \& pemberdayaan masyarakat. Citra Utama.

Tatàno, F., Caramiello, C., Paolini, T., \& Tripolone, L. (2017). Generation and collection of restaurant waste: Characterization and evaluation at a case study in Italy. Waste Management, 61, 423-442.

https://doi.org/10.1016/j.wasman.2017.01. 
020

Vaughn, J. (2009). Waste management: a reference handbook (Vol. 46). https://doi.org/10.5860/CHOICE.46-5638

Wahyono, S. (2001). Pengolahan Sampah Organik dan Aspek Sanitasi. PENGOLAHAN SAMPAH ORGANIK DAN ASPEK SANITASI, 2(2), 113-118.

Yuliastuti, Nyoman, Ayu, I., Yasa, Mahaendra, N. I., \& Jember, Made, i. (2013). SAMPAH DI KABUPATEN BADUNG sebagaimana mestinya jelas akan berdampak terhadap pencemaran lingkungan. E- Ekonomi Bisnis Universitas Udayana, 02, 374-393.
Zeng, C., Niu, D., Li, H., Zhou, T., \& Zhao, Y. (2016). Public perceptions and economic values of source-separated collection of rural solid waste: A pilot study in China. Resources, Conservation and Recycling, 107, 166-173. https://doi.org/10.1016/j.resconrec.2015.12 .010 